\title{
Current view of mesenchymal stem cells biology (brief review)
}

\author{
O. O. Maslova \\ Institute of Genetic and Regenerative Medicine, NAMS of Ukraine \\ 67, Vyshgorodska Str., Kyiv, Ukraine, 04114 \\ rotiferko@gmail.com
}

\begin{abstract}
Although mesenchymal stem cells (MSC) are in a focus of attention, some aspects of their biology are still unclear. This paper is a review of current research on MSC biology. The use of MSC in regenerative medicine is also briefly discussed.
\end{abstract}

Keywords: mesenchymal stem cells, regenerative medicine, cell cultivation

Mesenchymal stem (stromal) cells (MSC) are considered to be the most promising instrument of cell and tissue engineering. However, regardless of rather long-term detailed study of MSC in the cell culture there are still uninvestigated aspects of their biology. As a main "white spot" may be considered the absence of description of MSC properties in natural niches of the organism and in artificially created cultivation conditions. For instance, the author of [1] writes, "Mesenchymal stem cells (MSCs) have been well identified in cultures obtained from various human tissues. However, they give no clue as to their native identity, frequency, or anatomical location."

The objectivity of views on MSC is limited by the differences in the data about MSC properties, possibly acquired in artificial conditions of cultivation in laboratories, and by the attempts to adjust these properties to a specific set of phenotypic characteristics. The traditional definition of MSC as "clonogenic cells, capable of adhesing to plastic, expressing a specific set of surface markers and differentiating trilinearly" is insufficient and requires clarification.

MSC properties depend on their origin from mesenchyme - embryonic tissue, absent in the adult orga-

(C) Institute of Molecular Biology and Genetics, NAS of Ukraine, 2012 nism. Starlike cells of mesenchyme fill the cavities in the embryo organism, synthesize the molecules of intracellular matrix and thus support its architectonics. They are capable of amoeboid motion and phagocytosis [2]. The mesenchyme is formed during gastrulation. It is most likely that this tissue originates from all three germ layers [2-4]. This is what allows MSC of the adult organism to transform into tissue cells of both mesodermal line and ento- and ectodermal origin [3, 4]. Loose connective tissue is morphologically most close to the mesenchyme in the adult organism, as it contains a large amount of intercellular substance and fibroblasts. Also primitive connective tissues are reticular tissue of hematopoietic organs (bone marrow, spleen, etc.). The intermediary state between embryonic mesenchyme and adult connective tissue is taken by mucous connective tissue of the umbilical cord matrix (Wharton's jelly) (Fig.1) [5]. The phenomenon of reversible mesenchymal and epithelial transitions (MET-EMT) is observed both at a stage of organogenesis and during postnatal (normal and pathological) morphogenetic processes [6]. Such mutual transfers are characterized by morphological changes in cells (Table). There is an opinion that the of specificities of MET-EMT processes will allow understanding the of MSC nature in vivo [7, 8]. 

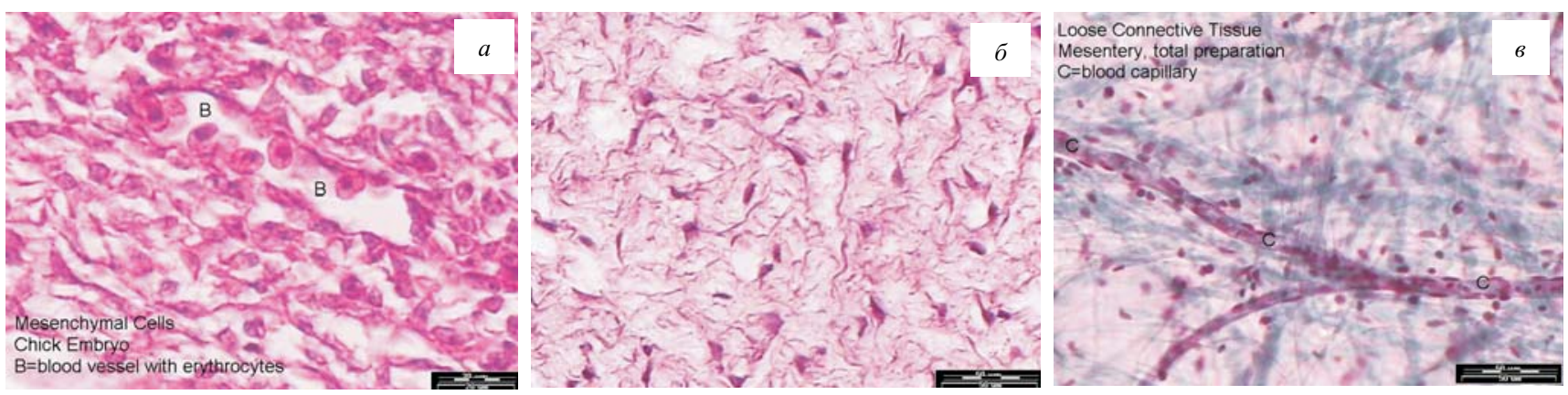

Fig.1 Comparison of the composition of mesenchyme and its derivatives (www.technion.ac.il/ mdcourse/): a - embryonic mesenchyme; b mucous tissue of the umbilical cord; c - loose connective tissue

Morphofunctional differences between the cells of epithelial and mesenchymal type [9]

\begin{tabular}{lll|}
\hline \multicolumn{1}{c|}{ Property } & \multicolumn{1}{c|}{ Epithelial cells } & Mesenchymal cells \\
\hline Cellular contacts & $\begin{array}{l}\text { Adhesive contacts (via E-cadherin), } \\
\text { desmosome, tight junctions }\end{array}$ & Absent or weak \\
Cytoskeleton & Cytokeratins & Vimentin \\
Synthesis of extracellular matrix & Laminin, collagen of type IV & Fibronectin, collagens I/III \\
Expression of proteases & Absent or weak & High (metalloproteinases) \\
\hline
\end{tabular}

Such transitions are most frequent during the formation of spatial organization of organs in the embryogenesis [9]. In the mature organism MET and EMT are remarkable for the processes of tissue regeneration as well as for the formation of fibroses, carcinomas and metastasis of tumors [10]. The transitions are regulated by the different signaling cascades [7-10]. Micro-RNA and post-translational modifications of proteins play a significant role in the mentioned processes with the impact of growth factors and cytokines [9].

Every year there appear new data on successful isolation of MSC in accord classic criteria from rather "exotic" sources, such as menstrual blood [11], teeth [12] and peripheral blood [13, 14]. According to some publications, MSC are present in the blood of healthy people [15-17], according to others - they are either absent [18] or appear only at some diseases or traumas, requiring their systemic mobilization (for instance, at severe burns) $[19,20]$. It was shown that MSC from peripheral blood have properties, analogous to MSC of bone marrow [14]. However, the main attention is paid to the cells, isolated from bone marrow, adipose tissue and fetal tissues (placenta, umbilical cord, etc.) [21, 22]. Contrary to the adult organism, where the mesenchyme is completely transformed to various connective tissues, the umbilical cord as a derivative of yolk sac and allantois contains a primitive form of extraembryonic mesenchyme - Wharton's jelly [23]. Its predominant part consists of fibroblast-like cells, actively synthesizing glycosaminoglycans. Some authors believe that MSC obtained from the umbilical cord matrix preserve not multipotent (like MSC of adults), but pluripotent [24] potential (there are data on the possibility of their expression of embryonic markers Oct4 and Tra-1-60, Tra1-81, SSEA1, SSEA-4, [25]); their immune phenotype somewhat differs from the mature one which opens additional opportunities for allotransplantations [26].

The first data on MSC were obtained in 1960-1970-s [27-31], but the issue of selecting a proper name for them was actively raised only in 2004-2006. Intensification of the work with these cells and expansion of sources of their isolation caused even more frequent suggestions of substituting the term "mesenchymal stem cells" with more precise definition, which would accurately reflects biological specificities of each population of these cells. The International Society for Cell Therapy recommended the term "multipotent stromal cells" [32]. However, nowadays there is less interest to terminology, therefore, the terms 
"mesenchymal stem cells" and "multipotent stromal cells" are almost as frequent in modern literature. The term "mesenchymal stem/stromal cells" also gained its ground.

One of the main problems of MSC biology is that all the places of their localization in the adult organism in vivo have not been revealed yet $[1,33-35]$. There are only some data about the niches of MSC in the bone marrow and perivascular sites, and it is shown that these cells can be isolated from other tissues as well. The data about MSC are related to in vitro systems [1,33-36] and one might assume that they have a considerably modified receptor portrait due to the procedures of isolation and reseeding [37-39]. Although MSC in the culture are described in detail, nowadays there is neither a specific marker nor even a clear-cut set of markers to determine MSC in the organism. The active search for the markers optimal combination for precise identification is carried out. The International Society for Cell Therapy made an attempt to present the MSC properties according to the required criteria [32], but, unfortunately, later they were proven to be insufficient for complete characterization of MSC. According to the recent recommendations of the International Society of Cell Therapy, the properties, common for all the MSC regardless of their origin and the method of isolation, are as follows: a capability of adhesion to plastic (the property, which may be observed even in the very cell culture, not in the organism), easy differentiation into chondro-, osteo-, and adipocytes, expression of CD105, CD90, CD73 and no expression of CD34, CD45, CD11, HLA-DR [32]. The list of other surface markers has considerable variations, depending on the origin of MSC. Among newly suggested positive markers are CD13, CD29, CD271, CD166, CD146, 140b, CD106, and others $[40,41]$. There are combinations of dozens and hundreds of surface markers, expressed by MSC, but there is no clear-cut recommended set yet.

Some differences were also revealed in the potential of differentiating the subpopulations of MSC, isolated from diversesources [35, 42].

Considerable difficulties are also related to the fact that the abovementioned positive markers are rather wide-spread among various cells of the organism. It makes it impossible to distinguish MSC from the neighboring cells, for instance, in tissue preparations. Thus,
CD105 (SH2), or endoglin, which is a glycoprotein, included into the composition of the receptor complex for TGF-beta, is expressed on the surface of endothelial cells, activated macrophages, fibroblasts and cells of smooth muscles [43], which makes it impossible to distinguish MSC from these types of cells. Besides MSC, CD90, or Thy-1, is also expressed on the surface of thymocytes, neurons, hematopoietic stem cells, NK-cells, endotheliocytes, renal cells, circulating melanoma cells, follicular-dendrite cells, fibroblasts and myofibroblasts [44]. The expression of CD73 (SH3/SH4), or ecto-5'-nucleotidase, is also remarkable for oligodendrocytes, B- and T-lymphocytes, neurons, perithelial cells, fibroblasts, cardiomyocytes and other types of cells [45]. There is an opinion about the suitability of these markers for the determination of MSC in the cases, when the presence of other types of cells is disregarded completely.

An assumption that the criteria for MSC determination in the culture may be related to other types of cells is stated more and more frequently [1].

The most complicated is the MSC determination right in the living organism [33-35, 46]. Despite successful MSCisolation from different tissues, their natural niches are described in detail only for bone marrow and perivascular regions $[1,39]$. The fibroblast-like, adhesive cells, capable of trilineardifferentiation and corresponding to the phenotypic criteria of MSC, were isolated from many tissues of the adult organism. Still, it is yet to be revealed which morphofunctional properties in vivo are remarkable for these cells [1]. Recently there have been some reports on different types of the adult organism, which might be capable of acquiring the properties of MSC in the culture [1,35]. These cells allegedly include perithelial cells, fibroblasts, myofibroblasts, reticular cells, intestinal cells and some others [47]. Most articles are devoted to fibroblasts [1, $35,48,49]$, as immediate derivatives of the mesenchyme, and to perithelial cells $[1,50]$ as the cells, inhabiting one of alleged niches of MSC. There is an assumption that these cells are in different functional states, including multipotent one. It is also probable that a definite (very small) amount of embryonic mesenchymal cells does not reach the final stages of differentiation and remains in the stem state as a regenerative pool. According to current views, MSC are a 
heterogeneous group of cells with stem properties [1, $35,51]$. It is considered that for better understanding of MSC state in vivo it is required thorough study of the chemical and cellular composition of MSC niches (which is currently worked on in the prominent laboratories of the world) as well as detailed elaboration of the notions of the functional and structural role of MSC in health and disease.

Being in the natural environment inside the organism, MSC interact both with molecules of the extracellular matrix and with each other as well as with other types of cells. According to the current data, the extracellular matrix is not only a mechanical support, but also a combination of ligands, launching definite signaling pathways via specific receptors [52]. The fate of MSC considerably depends on the matrix properties. The critical importance is attributed to both the nature of substances, surrounding the cells, and their physical characteristics, such as rigidity and flexibility (recent investigations prove that in some conditions the change in density and solidity of the substrate may play a key role in the selection of a way of MSC differentiation) [53-55].

Cell isolation from any tissue destructs (mechanically or enzymatically) both intercellular matrix and intercellular connections, thus causing considerable changes in the receptor portrait $[37,38]$ on the surface of the isolated cells. This phenomenon may be called "receptor shock" (Fig.2) which eliminates all the possibilities of cultivating native MSC. It is only after this serious restructuring in conditions of the culture of cells, which do not reproduce the composition of natural niches of the organism, that the cultivated material acquires the properties, described in vitro (Fig.3). These features help identifying MSC according to the known properties, but one should realize that they may differ from the properties of MSC, inherent to the organism. None of the current approaches to the optimization of cultivation conditions, in particular, an application of artificial or natural materials or bioreactors, allow accurate and precise reproduction of in vivo conditions. The multi-level regulation of the nervous, humoral, and immune activity of all cells in the organism is the least reproducible. Thus, summing up the abovementioned one may conclude that MSC is the name for the cells, acquiring a certain phenotype outside of the organism.

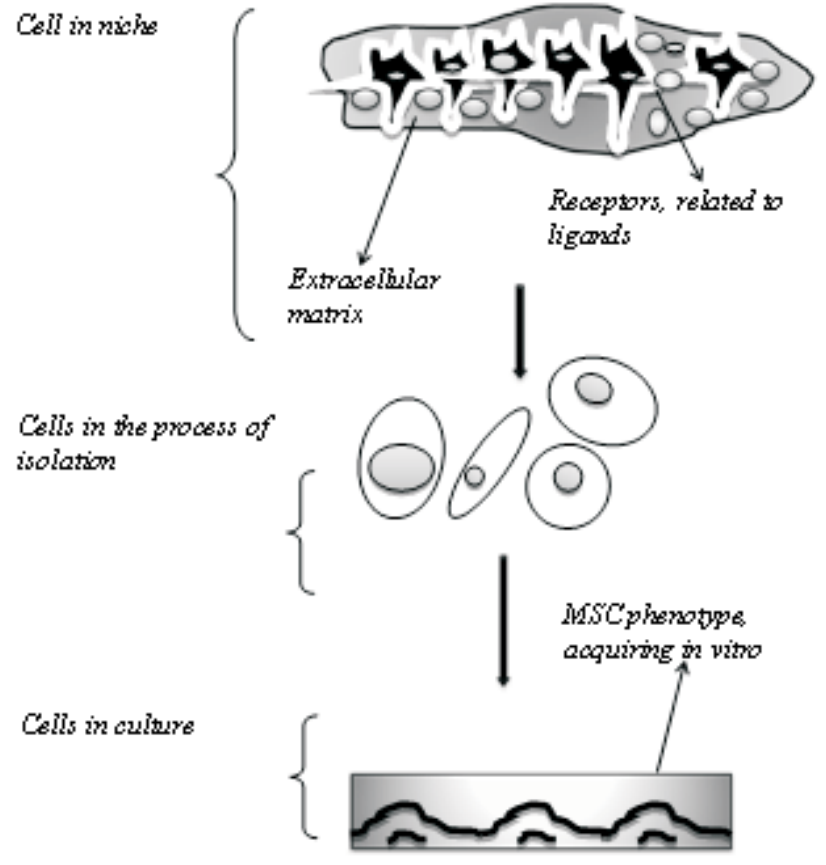

Fig.2 Schematic presentation of some cell modifications during obtaining the culture

One of vital issues is the possibility of long-term cultivation of MSC. According to the recent literature data, MSC are irreversibly modified with each consequent passage $[37,56,38]$. However, there are different opinions as to the passage of MSC cultivation without any loss of multipotency [57]. Some authors indicate feasible morphophysiological modifications of the cells and disorders of the expression of certain genes as early as at the stage of $2^{\text {nd }}-3^{\text {rd }}$ passages [58], others - at the $5^{\text {th }}-6^{\text {th }}$ passage [59]. The analysis of these data allows the conclusion about the absence of standardized methods of sustaining cells in the stable multipotent state.

The cultivated cells may be introduced into the experimental organism with different purposes. Partial evaluation of the efficiency of introduction of the cellular material requires tracking the ways of its migration. The modern methods of detecting the introduced MSC are as follows: PCR (RT-PCR), which allows determining the availability of Alu-sequences, specific for humans, and other markers in the animal organs, which were introduced with human MSC; staining with fluorescent proteins (with subsequent analysis of histological preparations or with the method of confocal microscopy in vivo) and labeling with radioactive 


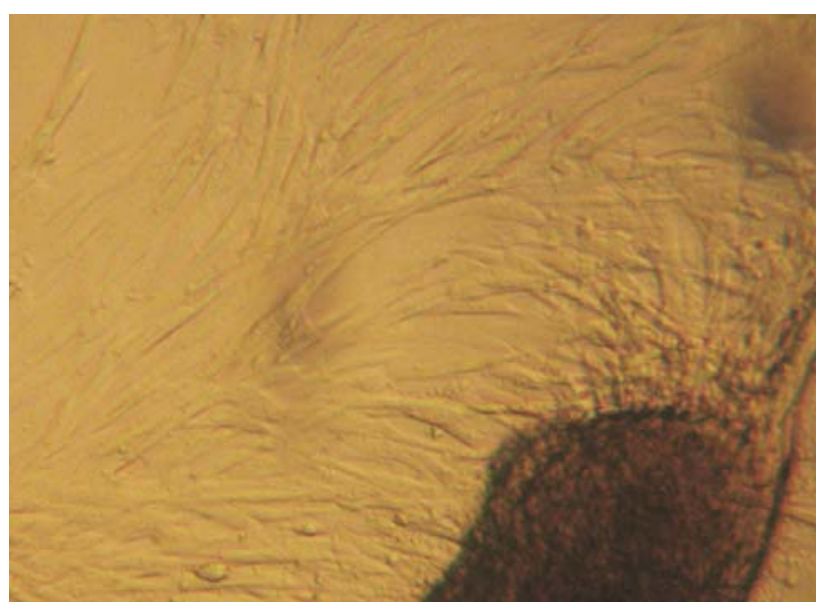

Fig.3 MSC culture, isolated from the matrix of human umbilical cord, passage 1 , unstained; $x 100$

particles; PET technology (positron emission tomography), magnetic resonance investigations [60-62]. According to the literature data, describing the distribution of MSC, systemically introduced into organisms of experimental animals from different sources, the cells are firstly detected in the lungs (approximately 70 $\%$ ), later they may be tracked in the liver (up to $15 \%$ ), kidneys (up to $20 \%$ ), spleen, heart and blood flow [62]. The data about the presence of the introduced MSC in the bone marrow are ambiguous. Some authors demonstrate the presence of exogenous MSC in the bone marrow [63], while others do not observed this phenomenon [64]. Up till now there is no univocal answer to the question, whether MSC are capable of self-destruction after the excretion of specific substances, whether they are transformed into the types of cells, necessary for the damaged organ, or undergo no modifications.

Various approaches in vivo allow understanding the specificities of homing and distribution of introduced cells. However, taking into consideration the potential modifications, inherent to pre-cultivated material, it is difficult to determine the MSC localization in tissue and organs $[1,65]$. Therefore, one of urgent tasks is the search for difference in the states of cells following the scheme: presence in a niche isolation from the tissue - cultivation - introduction into the organism - formation of a new niche on request (with subsequent differentiation or self-destruction after the release of paracrine factors, etc.)

Regardless of the mentioned difficulties, the cultivated MSC are already used in regenerative therapy [64-67]. There are attempts to decrease the impact of cultivation on MSC metabolism and to preserve their original characteristics. The xenogenic, allogenic, and autologous variants of MSC application were tested in experiments on animals. Human MSC are also actively introduced in clinical practice. The issue of clinical application of MSC from various sources has been highlighted in a number of extensive reviews [68-73], therefore, this work will only present a brief outline of the main approaches in regenerative medicine, where the application of MSC is required. There are several works, where cellular material was used in the phases $1-3$ of clinical trial [74, 75], however, the results are rather ambiguous. The stages 1 and 2 were rather successful in the most cases, but there was some disagreement about the stage 3, concerning suitability of application of MSC compared to traditional medical preparations. The review, cited in [76], is devoted to the discussion of this issue.

The cells, cultivated in vitro, may be introduced to the patient either locally (as, for instance, in case of treating joints or repairing wounds) or systemically (in particular, for the myocardial infarction). Systemic introduction requires the application of a suspension or cellular aggregates of minimal size in order to eliminate the risk of embolism. The application of MSC as carriers of certain substances (the most wide-spread among them being antitumor preparations) seems to be more and more probable [77]. The MSC with in-built genetic constructions acquire the capability of synthesizing and releasing the required substances [46, 77]. The problems, occurring in the course of applying MSC in regenerative medicine, are as follows: selection of optimal sources, cultivation without loss of stem characteristics, selection of an adequate method of introduction into the organism, possibility of tracking the fate of introduced material in the organism.

Although the clinical aspects are not reviewed in this work in detail, it is noteworthy to indicate the fields, where this material may be used, and to discuss shortly the reasons of MSC application. According to the literature data, the pathologies, which may be treated using MSC, include neurodegenerative [78] and autoimmune diseases $[79,80]$, cardiovascular diseases [81], strokes [82], diseases of locomotor system [83], traumas [84], tumors, including sarcomas [85]. The 
application of MSC in the clinical practice is related to their potential impact on the immune response [86], to the expressed paracrine effects (for instance, release of growth factors and cytokines) [68], and participation in the restoration of damaged tissues [87]. A number of modern studies indicate a considerably important role of paracrine effects of MSC introduction. Due to the capability of MSC to secrete growth factors, cytokines, and chemokines they may regulate the state of microenvironment and thus stimulate the regeneration of tissues. Numerous works are devoted also to the immunomodulating effects of MSC, in particular, their impact on various stages of the immune response was demonstrated in[88-91].

The analysis of current views on MSC biology allows the following conclusions:

- specific anatomic localization of MSC in the adult organism is determined only for the bone marrow, although these cells were detected in other tissues as well;

- up to now there is no definite formulation of a concept about MSC natural niches ;

- the procedures of MSC cultivation outside of the organism result in the changes in the receptor portrait and other characteristics of MSC, which does not permit precise evaluation of their properties;

- it still remains vague an issue of selecting maximally exhaustive markers, distinguishing MSC from other cells with similar phenotypic properties and allowing to demonstrate the MSC pool in different tissues.

More accurate definition may be proposed: MSC in culture is a heterogeneous group of multipotent cells, which are likely to acquire certain phenotypic properties after the isolation from different tissues: the expression of a set of surface markers, adhesion to plastic, capability of induced differentiation.

Thus, the understanding of cytological and biochemical specificities of MSC not only in culture, but also in living organism, is a key issue, the solution of which is required for their more efficient and safe application in clinical practice. Current works, directed towards the preparation of MSC for their application in regenerative medicine, should be aimed at decreasing the consequences of cell cultivation and search for the ways of their long-term sustaining in the culture without any modifications.

\section{О. А. Маслова}

Современные взгляды на биологию мезенхимальных стволовых клеток (краткое изложение)

ГУ «Институт генетической и регенеративной медицины HAMHУ $\rangle$

Ул. Вышгородская, 67, Киев, Украина, 04114

В настоящее время мезенхимальным стволовым клеткам (МСК) уделяется достаточно большое внимание, однако до сих пор не раскрытыли остаются некоторые аспекты их биологии. В обзоре представлены материаль современных исследований, посвященные проблемным вопросам биологии МСК. Кратко обсуждается возможность использования МСК в регенеративной медицине

Ключевые слова: мезенхимальные стволовые клетки, регенеративная медицина, культивирование клеток

\section{О. О. Маслова}

Сучасні погляди на біологію мезенхімальних стовбурових клітин (короткий виклад)

На сьогодні мезенхімальним стовбуровим клітинам (МСК) приділяють досить значну увагу, однак досі не розкритими залишаються деякі аспекти їхньої біологї. В огляді представлено матеріали сучасних досліджень, присвячених проблемним питанням біології МСК. Коротко обговорюється можливість використання МСК у регенеративній медицині.

Ключові слова: мезенхімальні стовбурові клітини, регенеративна медицина,культивування клітин.

\section{REFERENCES}

1. Can A. Searching for in vivo traces of mesenchymal stem cells and their ancestors // Adult and embryonic stem cells / Ed. K. Turksen.-Amsterdam: Springer, 2012.-P. 11-24.

2. Strum J. M., Gartner L. P., Hiatt J. L. Cell biology and histology.-Hagerstwon: Lippincott Williams \& Wilkins, 2007.-83 p.

3. Gunin A. G. Gistologiya v tablitsah i schemah.-Moscow: PM, 2009. -83 p.

4. Selezneva T., Mishyn A., Barsukow V. Gistologiya: polnyi kurs za tri dnya.-Moscow: Eksmo, 2007.-354 p.

5. Taghizadeh R. R., Cetrulo K. J., Cetrulo C. L. Wharton's jelly stem cells: future clinical applications // Placenta.-2011.-32, Supp1 4.-S311-315.

6. Lee R. H., Pulin A. A., Seo M. J., Kota D. J., Ylostalo J., Larson B. L., Semprun-Prieto L., Delafontaine P., Prockop D. J. Intravenous hMSCs improve myocardial infarction in mice because cells embolized in lung are activated to secrete the anti-inflammatory protein TSG-6 // Cell Stem Cell.-2009.-5, N 1.P. 54-63.

7. Wang Z., Li Y., Ahmad A., Azmi A. S., Kong D., Banerjee S., Sarkar F. H. Targeting miRNAs involved in cancer stem cell and EMT regulation: an emerging concept in overcoming drug resistance // Drug Resist. Updat.-2010.-13, N 4-5.-P. 109-118.

8. Thiery J. P., Acloque H., Huang R. Y., Nieto M. A. Epithelialmesenchymal transitions in development and disease // Cell.2009.-139, N 5.-P. 871-890. 
9. Kalluri R. EMT: when epithelial cells decide to become mesenchymal-like cells // J. Clin. Invest.-2009.-119, N 6.-P. 14171419.

10. Kalluri R., Zeisberg M. Fibroblasts in cancer//Nat. Rev. Cancer.2006.-6, N 5.-P. 392-401.

11. Patel A. N., Park E., Kuzman M., Benetti F., Silva F. J., Allickson J. G. Multipotent menstrual blood stromal stem cells: isolation, characterization, and differentiation // Cell Transplant.2008.-17, N 3.-P. 303-311.

12. Huang G. T., Gronthos S., Shi S. Mesenchymal stem cells derived from dental tissues vs. those from other sources: their biology and role in regenerative medicine // J. Dent. Res.-2009.-88, N 9.-P. 792-806.

13. Ukai R., Honmou O., Harada K., Houkin K., Hamada H., Kocsis $J$. D. Mesenchymal stem cells derived from peripheral blood protects against ischemia // J. Neurotrauma.-2007.-24, N 3.P. 508-520.

14. Chong P. P., Selvaratnam L., Abbas A. A., Kamarul T. Human peripheral blood derived mesenchymal stem cells demonstrate similar characteristics and chondrogenic differentiation potential to bone marrow derived mesenchymal stem cells // J. Orthop. Res.-2012.-30, N 4.-P. 634-642.

15. Rochefort G. Y., Delorme B., Lopez A., Herault O., Bonnet P., Charbord P., Eder V., Domenech J. Multipotential mesenchymal stem cells are mobilized into peripheral blood by hypoxia // Stem Cells.-2006.-24, N 10.-P. 2202-2208.

16. Zvaifler N. J., Marinova-Mutafchieva L., Adams G., Edwards C. J., Moss J., Burger J., Maini R. N. Mesenchymal precursor cells in the blood of normal individuals // Arthritis Res.-2000.-2, N 6.P. $477-488$.

17. Kuznetsov S. A., Mankani M. H., Gronthos S., Satomura K., Bianco P., Robey P. G. Circulating skeletal stem cells // J. Cell Biol.-2001.-153, N 5 -P. 1133-1140.

18. Wexler S. A., Donaldson C., Denning-Kendall P., Rice C., Bradley B., Hows J. M. Adult bone marrow is a rich source of human mesenchymal «stem» cells but umbilical cord and mobilized adult blood are not // Br. J. Haematol.-2003.-121, N 2 -P. 368-374.

19. Mansilla E., Marin G. H., Drago H., Sturla F., Salas E., Gardiner C., Bossi S., Lamonega R., Guzman A., Nunez A., Gil M. A., Piccinelli G., Ibar R., Soratti C. Bloodstream cells phenotypically identical to human mesenchymal bone marrow stem cells circulate in large amounts under the influence of acute large skin damage: new evidence for their use in regenerative medicine // Transplant. Proc.-2006.-38, N 3.-P. 967-969.

20. Kassis I., Zangi L., Rivkin R., Levdansky L., Samuel S., Marx G., Gorodetsky $R$. Isolation of mesenchymal stem cells from GCSF-mobilized human peripheral blood using fibrin microbeads // Bone Marrow Transplant.-2006.-37, N 10.-P. 967-976.

21. Hass R., Kasper C., Bohm S., Jacobs R. Different populations and sources of human mesenchymal stem cells (MSC): a comparison of adult and neonatal tissue-derived MSC // Cell Commun. Signal.-2011.-9.-P. 12.

22. Bieback K., Brinkmann I. Mesenchymal stromal cells from human perinatal tissues: from biology to cell therapy // World J. Stem Cells.-2010.-2, N 4.-P. 81-92.

23. Can A., Karahuseyinoglu S. Concise review: human umbilical cord stroma with regard to the source of fetus-derived stem cells // Stem Cells.-2007.-25, N 11.-P. 2886-2895.

24. Fong C. Y., Richards M., Manasi N., Biswas A., Bongso A. Comparative growth behaviour and characterization of stem cells from human Wharton's jelly // Reprod. Biomed. Online.2007.-15, N 6.-P. 708-718.

25. Anzalone R., Lo Iacono M., Corrao S., Magno F., Loria T., Cappello F., Zummo G., Farina F., La Rocca G. New emerging potentials for human Wharton's jelly mesenchymal stem cells: immunological features and hepatocyte-like differentiative capacity // Stem Cells Dev.-2010.-19, N 4.-P. 423-438.

26. Fong C. Y., Chak L. L., Biswas A., Tan J. H., Gauthaman K., Chan W. K., Bongso A. Human Wharton's jelly stem cells have unique transcriptome profiles compared to human embryonic stem cells and other mesenchymal stem cells // Stem Cell Rev.2011.-7, N 1.-P. 1-16.

27. Becker A. J., McCulloch E. A., Till J. E. Cytological demonstration of the clonal nature of spleen colonies derived from transplanted mouse marrow cells // Nature.-1963.-197, N 4866.-P. 452-454.

28. Siminovitch L., McCulloch E. A., Till J. E. The distribution of colony-forming cells among spleen colonies // J. Cell. Comp. Physiol.- 1963.-62, N 3.-P. 327-336.

29. Friedenstein A. J., Deriglasova U. F., Kulagina N. N., Panasuk A. F., Rudakowa S. F., Luria E. A., Ruadkow I. A. Precursors for fibroblasts in different populations of hematopoietic cells as detected by the in vitro colony assay method // Exp. Hematol.1974.-2, N 2.-P. 83-92.

30. Friedenstein A. J., Gorskaja J. F., Kulagina N. N. Fibroblast precursors in normal and irradiated mouse hematopoietic organs // Exp. Hematol.-1976.-4, N 5.-P. 267-274.

31. Pittenger M. F., Mackay A. M., Beck S. C., Jaiswal R. K., Douglas R., Mosca J. D., Moorman M. A., Simonetti D. W., Craig S., Marshak D. R. Multilineage potential of adult human mesenchymal stem cells // Science.-1999.--284, N 5411.-P. 143-147.

32. Dominici M., Le Blanc K., Mueller I., Slaper-Cortenbach I., Marini F., Krause D., Deans R., Keating A., Prockop Dj., Horwitz $E$. Minimal criteria for defining multipotent mesenchymal stromal cells. The International Society for Cellular Therapy position statement // Cytotherapy.-2006.-8, N 4.-P. 315-317.

33. Augello A., Kurth T. B., De Bari C. Mesenchymal stem cells: a perspective from in vitro cultures to in vivo migration and niche // Eur. Cell Mater.-2010.-20.-P. 121-133.

34. Lindner U., Kramer J., Rohwedel J., Schlenke P. Mesenchymal stem or stromal cells: toward a better understanding of their biology? // Transfus. Med. Hemother.-2010.-37, N 2 -P. 75-83.

35. Ulrich C., Hart M. L., Rolauffs B., Abele H., Gotze M., Benz K., Aicher $W$. K. Mesenchymal stromal cells and fibroblasts // J. Tissue Sci. Eng.-2012.-3.-e109.

36. Nombela-Arrieta C., Ritz J., Silberstein L. E. The elusive nature and function of mesenchymal stem cells // Nat. Rev. Mol. Cell Biol.-2011.-12, N 2.-P. 126-131.

37. Rombouts W. J., Ploemacher R. E. Primary murine MSC show highly effcient homing to the bone marrow but lose homing ability following culture // Leukemia.-2003.-17, N 1.-P. 160-170.

38. Sarkar D., Spencer J. A., Phillips J. A., Zhao W., Schafer S., Spelke D. P., Mortensen L. J., Ruiz J. P., Vemula P. K., Sridharan R., Kumar S., Karnik R., Lin C. P., Karp J. M. Engineered cell homing // Blood.-2011.-118, N 25.-e184-191.

39. Jones E., McGonagle D. Human bone marrow mesenchymal stem cells in vivo // Rheumatology (Oxford).-2008.-47, N 2.P. 126-131.

40. Buhring H. J., Battula V. L., Treml S., Schewe B., Kanz L., Vogel $W$. Novel markers for the prospective isolation of human MSC // Ann. N. Y. Acad. Sci.-2007.-1106.-P. 262-271.

41. Covas D. T., Panepucci R. A., Fontes A. M., Silva W. A., Orellana M. D., Freitas M. C., Neder L., Santos A. R., Peres L. C., Jamur M. C., Zago M. A. Multipotent mesenchymal stromal cells obtained from diverse human tissues share functional properties 
and gene-expression profile with $\mathrm{CD} 146^{+}$perivascular cells and fibroblasts // Exp. Hematol.-2008.-36, N 5.-P. 642-654.

42. Molchanova E. A., Bueverova E. I., Starostin V. I., Domaratskaya $E$. I. The sensitivity of mesenchymal stromal cells subpopulations with different adhesion properties and derived from hemopoietic organs // Izv. Akad. Nauk Ser. Biol.-2011.-N 2.- P. 133-144.

43. Bussolati B., Bruno S., Grange C., Ferrando U., Camussi G. Identification of a tumor-initiating stem cell population in human renal carcinomas // FASEB J.-2008.-22, N 10.-P. 36963705 .

44. De Francesco F., Tirino V., Desiderio V., Ferraro G., D'Andrea F., Giuliano M., Libondi G., Pirozzi G., De Rosa A., Papaccio $G$. Human $\mathrm{CD} 34^{+} / \mathrm{CD} 90^{+} \mathrm{ASC}$ are capable of growing as sphere clusters, producing high levels of VEGF and forming capillaries // PLoS ONE.-2009.-4, N 8.-e6537.

45. Hunsucker S. A., Mitchell B. S., Spychala J. The 5'-nucleotidases as regulators of nucleotide and drug metabolism // Pharmacol. Ther.-2005.-107, N 1.-P. 1-30.

46. Baksh D., Song L., Tuan R. S. Adult mesenchymal stem cells: characterization, differentiation, and application in cell and gene therapy // J. Cell. Mol. Med.-2004.-8, N 3.-P. 301-316.

47. Corselli M., Chen C. W., Crisan M., Lazzari L., Peault B. Perivascular ancestors of adult multipotent stem cells // Arterioscler. Thromb. Vasc. Biol.-2010,-30, N 6.-P. 1104-1109.

48. Haniffa M. A., Collin M. P., Buckley C. D., Dazzi F. Mesenchymal stem cells: the fibroblasts' new clothes? // Haematologica.2008.-94, N 2.-P. 258-263.

49. Bozo I., Deev R. V., Pinaev G. P. Is «fibroblast» a specialized cell or a functional condition of mesenchymal cells derivatives? // Tsitologiia.-2010.-52, N 2.-P. 99-109.

50. Crisan M., Yap S., Casteilla L., Chen C. W., Corselli M., Park T. S., Andriolo G., Sun B., Zheng B., Zhang L., Norotte C., Teng P. N., Traas J., Schugar R., Deasy B. M., Badylak S., Buhring H. J., Giacobino J. P., Lazzari L., Huard J., Peault B. A perivascular origin for mesenchymal stem cells in multiple human organs // Cell Stem Cell.-2008.-3, N 3.-P. 301-313.

51. Wuchter P., Wagner W., Ho A. D. Mesenchymal stem cells: an oversimplified nomenclature for extremely heterogeneous progenitors // Regenerative Medicine / Ed. G. Steinhoff.-Heidelberg: Springer, 2011.-Pt 2.-P. 377-395.

52. Reilly G. C., Engler A. J. Intrinsic extracellular matrix properties regulate stem cell differentiation // J. Biomech.-2010.-43, N 1.-P. 55-62.

53. Tse J. R., Engler A. J. Stiffness gradients mimicking in vivo tissue variation regulate mesenchymal stem cell fate // PLoS ONE.2011.-6, N 1.-e15978.

54. Peyton S. R., Kalcioglu Z. I., Cohen J. C., Runkle A. P., Van Vliet K. J., Lauffenburger D. A., Griffith L. G. Marrow-derived stem cell motility in $3 \mathrm{D}$ synthetic scaffold is governed by geometry along with adhesivity and stiffness // Biotechnol. Bioeng.2011.-108, N 5-P. 1181-1193.

55. Huebsch N., Arany P. R., Mao A. S., Shvartsman D., Ali O. A., Bencherif S. A., Rivera-Feliciano J., Mooney D. J. Harnessing traction-mediated manipulation of the cell/matrix interface to control stem-cell fate // Nat. Mater.-2010.-9, N 6. -P. 518-526.

56. Wagner W., Horn P., Castoldi M., Diehlmann A., Bork S., Saffrich R., Benes V., Blake J., Pfister S., Eckstein V., Ho A. D. Replicative senescence of mesenchymal stem cells: a continuous and organized process // PLoS ONE.-2008.-3, N 5.-e2213

57. Osipova E. Y., Shamanskaya T. V., Kurakina O. A., Nikitina V. A. Purbueva B. B., Ustugov A. Y., Kachanov D. Y., Skorobogatova E. V., Dishlevaya Z. M., Roumiantsev S. A. Biological characteristics of mesenchymal stem cells during ex vivo expansion // Br. J. Med. Med. Res.-2011.-1, N 3.-P. 85-95.
58. Angelucci S., Marchisio M., Di Giuseppe F., Pierdomenico L., Sulpizio M., Eleuterio E., Lanuti P., Sabatino G., Miscia S., Di Ilio $C$. Proteome analysis of human Wharton's jelly cells during in vitro expansion // Proteome Sci.-2010.-8.-P. 18.

59. Chong P. P., Selvaratnam L., Abbas A. A., Kamarul T. Human peripheral blood derived mesenchymal stem cells demonstrate similar characteristics and chondrogenic differentiation potential to bone marrow derived mesenchymal stem cells // J. Orthop. Res.-2012.-30, N 4.-P. 634-642.

60. Kraitchman D. L., Tatsumi M., Gilson W. D., Ishimori T., Kedziorek D., Walczak P., Segars W. P., Chen H. H., Fritzges D. Izbudak I., Young R. G., Marcelino M., Pittenger M. F., Solaiyappan M., Boston R. C., Tsui B. M., Wahl R. L., Bulte J. W. Dynamic imaging of allogeneic mesenchymal stem cells trafficking to myocardial infarction // Circulation.-2005.-112, N 10.P. 1451-1461.

61. Hara M., Murakami T., Kobayashi E. In vivo bioimaging using photogenic rats: fate of injected bone marrow-derived mesenchymal stromal cells // J. Autoimmun.-2008.-30, N 3 -P. 163-171.

62. Schmidtke-Schrezenmeier G., Urban M., Musyanovych A., Mailander V., Rojewski M., Fekete N., Menard C., Deak E., Tarte K., Rasche V., Landfester K., Schrezenmeier $H$. Labeling of mesenchymal stromal cells with iron oxide-poly(L-lactide) nanoparticles for magnetic resonance imaging: uptake, persistence, effects on cellular function and magnetic resonance imaging properties // Cytotherapy.-2011.-13, N 8.-P. 962-975.

63. Li Z. H., Liao W., Cui X. L., Zhao Q., Liu M., Chen Y. H., Liu T. S., Liu N. L., Wang F, Yi Y., Shao N. S. Intravenous transplantation of allogeneic bone marrow mesenchymal stem cells and its directional migration to the necrotic femoral head // Int. J. Med. Sci.-2011.-8, N 1.-P. 74-83.

64. Spencer N. D., Gimble J. M., Lopez M. J. Mesenchymal stromal cells: past, present, and future // Vet. Surg.-2011.-40, N 2.P. 129-139.

65. Mani S. A., Guo W., Liao M. J., Eaton E. N., Ayyanan A., Zhou A. Y., Brooks M., Reinhard F., Zhang C. C., Shipitsin M., Campbell L. L., Polyak K., Brisken C., Yang J., Weinberg R. A.The epithelial-mesenchymal transition generates cells with properties of stem cells // Cell.-2008.-133, N 4.-P. 704-715.

66. Bianco P., Robey P. G., Simmons P. J. Mesenchymal stem cells: revisiting history, concepts, and assays // Cell Stem Cell.-2008.2, N 4.-P. 313-319.

67. Salem H. K., Thiemermann C. Mesenchymal stromal cells: current understanding and clinical status // Stem Cells.-2010.-28, N 3.-P. 585-596.

68. Bernardo M. E., Pagliara D., Locatelli F. Mesenchymal stromal cell therapy: a revolution in regenerative medicine? // Bone Marrow Transplant.-2012.-47, N 2.-P. 164-171.

69. Herberts C. A., Kwa M. S., Hermsen H. P. Risk factors in the development of stem cell therapy // J. Transl. Med.-2011.-9.-P. 29.

70. Sensebe L., Bourin P., Tarte K. Good manufacturing practices production of mesenchymal stem/stromal cells // Hum. Gene Ther.-2011.-22, N 1.-P. 19-26.

71. Lasala G. P., Minguell J. J. Vascular disease and stem cell therapies // Br. Med. Bull.-2011.-98.-P. 187-197.

72. Si Y. L., Zhao Y. L., Hao H. J., Fu X. B., Han W. D. MSCs: Biological characteristics, clinical applications and their outstanding concerns // Ageing Res. Rev.-2011.-10, N 1.-P. 93-103.

73. Parekkadan B., Milwid J. M. Mesenchymal stem cells as therapeutics // Annu. Rev. Biomed. Eng.-2010.-12.-P. 87-117.

74. Mazzini L., Ferrerob I., Luparello V., Rustichelli D., Gunetti M., Mareschi K., Testa L., Stecco A., Tarletti R., Miglioretti M., Fava E., Nasuelli N., Cisari C., Massara M., Vercelli R., Oggioni G., Carriero A., Cantello R., Monaco F., Fagioli F. Mesenchy- 
mal stem cell transplantation in amyotrophic lateral sclerosis: A Phase I clinical trial // Exp. Neurol.-2010.-223, N 1.-P. 229-237.

75. Bourin P., Sensebe L., Planat-Benard V., Roncalli J., Bura-Riviere A., Casteilla L. Culture and use of mesenchymal stromal cells in phase I and II clinical trials // Stem Cells Int.-2010.2010.-doi: $10.4061 / 2010 / 503593$.

76. Ankrum J., Karp J. M. Mesenchymal stem cell therapy: two steps forward, one step back // Trends Mol. Med.-2010.-16, N 5.P. 203-209.

77. Loebinger M. R., Janes S. M. Stem cells as vectors for antitumour therapy // Thorax.-2010.-65, N 4.-P. 362-369.

78. Joyce N., Annett G., Wirthlin L., Olson S., Bauer G., Nolta J. Mesenchymal stem cells for the treatment of neurodegenerative disease // Regen. Med.-2010.-5, N 6.-P. 933-946.

79. Uccelli A., Prockop D. J. Why should mesenchymal stem cells (MSCs) cure autoimmune diseases? // Curr. Opin. Immunol.2010.-22, N 6.-P. 768-774.

80. Tyndall A., Uccelli A. Multipotent mesenchymal stromal cells for autoimmune diseases: teaching new dogs old tricks // Bone Marrow Transplant.-2009.-43, N 11.-P. 821-828.

81. Hatzistergos K. E., Blum A., Ince T., GrichnikJ. M., Hare J. M. What is the oncologic risk of stem cell treatment for heart disease? // Circ. Res.-2011.-108, N 11.-P. 1300-1303.

82. Lee J. S., Hong J. M., Moon G. J., Lee P. H., Ahn Y. H., Bang O. Y. A long-term follow-up study of intravenous autologous mesenchymal stem cell transplantation in patients with ischemic stroke // Stem Cells.-2010.-28, N 6.-P. 1099-1106.

83. Richter $W$. Mesenchymal stem cells and cartilage in situ regeneration // J. Intern. Med.-2009.-266, N 4.-P. 390-405.

84. Jackson W. M., Lozito T. P., Djouad F., Kuhn N. Z., Nesti L. J., Tuan R. S. Differentiation and regeneration potential of mesen- chymal progenitor cells derived from traumatized muscle tissue // J. Cell Mol. Med.-2011.-15, N 11.-P. 2377-2388.

85. Ciavarella S., Dominici M., Dammacco F., Silvestris F. Mesenchymal stem cells: a new promise in anticancer therapy // Stem Cells Dev.-2011.-20, N 1-P. 1-10.

86. Herrero C., Perez-Simon J. A. Immunomodulatory effect of mesenchymal stem cells // Braz. J. Med. Biol. Res.-2010.-43, N 5.P. 425-430.

87. Hanson S. E., Gutowski K. A., Hematti P. Clinical applications of mesenchymal stem cells in soft tissue augmentation // Aesthet. Surg. J.-2010.-30, N 6.-P. 838-842.

88. Hoogduijn M. J., Roemeling-van Rhijn M., Korevaar S. S., Engela A. U., Weimar W., Baan C. C. Immunological aspects of allogeneic and autologous mesenchymal stem cell therapies // Hum. Gene Ther.-2011.-22, N 12.-P. 1587-1591.

89. Menard $C$., Tarte $K$. Immunosuppression and mesenchymal stem cells: back to the future // Med. Sci. (Paris).-2011.-27, N 3.P. 269-274.

90. Marigo I., Dazzi F. The immunomodulatory properties of mesenchymal stem cells // Semin. Immunopathol.-2011.-33, N 6.P. 593-602.

91. Hoogduijn M. J., Popp F., Verbeek R., Masoodi M., Nicolaou A., Baan C., Dahlke M. H. The immunomodulatory properties of mesenchymal stem cells and their use for immunotherapy // Int. Immunopharmacol.-2010.-10, N 12.-P. 1496-1500.

Received 11.11.11 